Rev. salud pública. 10 (5):788-795, 2008

\title{
Obesity and Dental Caries among Preschool Children in Brazil
}

\author{
Obesidad y caries dental en preescolares de Brasil
}

Ana F. Granville-Garcia, Valdenice A. de Menezes, Pedro I. de Lira, Jainara M Ferreira and Alessandro Leite-Cavalcanti

Universidade Estadual da Paraíba, Campina Grande, Paraíba, Brasil. anaflaviagg@hotmail.com; valdenicemenzes@terra.com.br; lirapic@ufpe.br; jainara.s@ig.com.br; dralessandro@ibest.com.br.

Received $9^{\text {th }}$ April 2008/Sent for Modification $12^{\text {th }}$ October/Accepted $10^{\text {th }}$ November

\begin{abstract}
Aim This study was aimed at verifying the relationship between childhood obesity and dental caries.

Method A total of 2651 preschool children were examined for this cross-sectional study in Recife, Pernambuco, Brazil; 1338 of them attended public schools and 1313 private schools. The clinical data and anthropometric measurements were obtained in line with WHO criteria. Pearson chi-square and Mann-Whitney tests were used, with a $5 \%$ margin of error.

Results The prevalence of child obesity was $9 \%(n=240)$. The highest prevalence was observed amongst children in private elementary schools $(p<0.0001)$. The prevalence of dental caries was $19 \%(n=504)$. The DMFT index was smaller in non-obese individuals $(p=0.0267)$. The average value of dental caries, lost teeth and DMFT were significantly higher among children in public elementary schools than amongst those in private pre-schools $(p<0.0001)$.

Conclusion No relationship was found between dental caries and obesity. Suitable health policies should be adopted so as to minimise the high prevalence of dental caries among this population.
\end{abstract}

Key Words: Epidemiology, dental caries, obesity, preschool child, decayed, missing and filled teeth score (source: $M e S H, N L M$ ).

\section{RESUMEN}

Objetivo Verificar la relación entre obesidad infantil y caries dental.

Métodos Estudio de corte transversal en Pernambuco, Brasil, con 2651 niños preescolares, de los cuales 1338 se encontraban en escuelas públicas y 1313 en escuelas privadas. La información clínica y antropométrica se obtuvo de acuerdo con los criterios de la OMS. Se utilizaron las pruebas de Chi cuadrado de Pearson y MannWhitney con un error del $5 \%$.

Resultados La prevalencia de obesidad infantil fue de $9 \%(n=240)$. La prevalencia más alta se encontró en los niños de las escuelas primarias privadas ( $p<0.0001)$. La 
prevalencia de caries dental fue de $19 \%(n=504)$. El dmf-t índice fue más pequeño en los individuos no obesos ( $p=0.0267$ ). El valor promedio de caries dental, pérdida dental y dmf-t fueron significativamente más altas en los niños de las escuelas primarias públicas que en las privadas del mismo tipo ( $p<0.0001)$.

Conclusiones No se encontró relación entre caries dental y obesidad. Políticas de salud adecuadas deben ser adoptadas para reducir la alta prevalencia de caries dental en esta población.

Palabras Clave: Epidemiología, caries dental, obesidad, preescolares (fuente: DeCS, BIREME).

\section{RESUMO}

Obesidade e Cárie Dentária em Pré-Escolares Brasileiros

Objetivo Este estudo objetivou verificar a relação entre obesidade infantil e cárie dentária.

Material e Métodos Neste estudo transversal um total de 2651 pré-escolares, sendo 1338 pertencentes a escolas públicas e 1313 de escolas privadas foram examinadas em Recife, Pernambuco, Brasil. Os exames clínicos e antropométricos foram realizados de acordo com os critérios estabelecidos pela OMS. Os testes do Quiquadrado de Pearson e Mann-Whitney foram empregados com margem de erros de $5 \%$.

Resultados A prevalência de obesidade entre as crianças foi de $9 \%(n=240)$. A maior prevalência foi observada entre as crianças de escolas públicas ( $p<0,0001)$. A prevalência de cárie dentária foi de $19 \%(n=504)$. O índice ceo-d foi menor em crianças não obesas ( $p=0,0267)$. Os valores médios de cárie dentária, dentes perdidos e ceo- $d$ foram significativamente mais elevados entre as crianças de escolas públicas do que entre as pertencentes às escolas particulares ( $p<0,0001)$.

Conclusão Não foi observada relação entre cárie dentária e obesidade. Políticas adequadas de saúde devem ser adotadas objetivando minimizar a alta prevalência de cárie dentária nesta população.

Palavras Chave: Epidemiologia, cárie dentária, obesidade, pré-escolares (fonte: DeCS, BIREME).

$\mathrm{O}$ besity and overweight are defined as being an excess of body fat related to lean mass, with multifactor conditions, involving psychological, biochemical, metabolic, anatomic and social alterations (1).

Spending too much time watching television or playing electronic games together with substituting industrialised food (rich in carbohydrates/fats and poor in fibre) for processed foodstuffs are the main causes of obesity and overweight $(2,3)$. 
Being overweight and developing obesity being found at ever earlier ages has worried experts (4). This pathology's prevalence in childhood and adolescence may be considered high, being between 5,5\% and $20 \%(5-8)$. Childhood obesity presents both immediate and long-term health risks such as orthopaedic consequences, hypertension, hypercholesterolemia, insulin resistance and adult obesity (9).

On the other hand, dental caries is described as being an imbalance between dental structure and buccal route where cariogenic microbiota, carbohydraterich diets and susceptible host are responsible for the disease's initiation and progression. The modern concept of dental caries includes social and behavioural factors regarding a particular individual (10). Although the current literature reports a decline in dental caries (11-14), this pathology's prevalence amongst preschoolers can still be considered high, being between 12,3 \% and 76,1\% (15-21).

As diet is a risk factor common to both obesity and dental caries, this study was set to explore the relationship between them amongst preschoolers from public and private elementary schools in the city of Recife, PE, Brazil.

\section{MATERIALS AND METHODS}

This study was approved by the Ethics' Committee of the University of Pernambuco (Pernambuco, Brazil). Two thousand, six hundred and fifty-one preschoolers (1-5 years old) were recruited from eighty-four public and private elementary schools in the city of Recife, Brazil, after their parents had signed an informed consent-form.

The prevalence of dental caries was obtained using World Health Organisation (WHO) standard criteria for dental caries diagnosis (22). The clinical examination was performed in natural light, children being in the kneeto-knee position (children less than two years of age) or sitting in chairs in elementary school rooms. Caps, masks, gloves and gauze were used in accordance with infection control guidelines. The data was collected by one previously trained researcher (kappa $=0.92$ ). Children presenting treatment needs were referred to Health Units or to the Dental School for dental care.

Regarding anthropometric assessment, a $150 \mathrm{KG}$ digital scale, a $100 \mathrm{~g}$ scale (Filizola) and a $200 \mathrm{~cm}$ tape (Stanley) were used according to WHO criteria (23) and National Centre for Health Statistics guidelines. Children with a Z 
score higher than 2 for the weight-height relationship were considered to be overweight.

SPSS (Statistical Package for the Social Sciences) version 11.0 was used for statistical analysis. Absolute and percentage frequencies were obtained for data analysis (descriptive statistical techniques). The existence of significant association amongst the variables was verified by means of bivariate analysis (Pearson chi-square and Mann-Whitney tests), á=0.05 being considered for rejecting the null hypothesis.

\section{RESULTS}

A total of 2651 children were examined, 1313 of whom were enrolled in private establishments and 1,338 in public ones (Table 1).

Table 1. Distribution of children according to gender and type of institution

\begin{tabular}{cccc}
\hline Age (years) & Private institution & Public institution & Total \\
\hline 1 & 61 & 169 & 230 \\
2 & 152 & 263 & 415 \\
3 & 293 & 296 & 589 \\
4 & 376 & 282 & 658 \\
5 & 431 & 328 & 759 \\
\hline Total & 1313 & 1338 & 2651 \\
\hline
\end{tabular}

Table 2 shows a high prevalence of children's obesity in private elementary schools $(p<0,001)$. The prevalence of infantile obesity was $9 \%(n=240)$. Table 3 evidences the prevalence of dental caries according to type of elementary school. Dental caries prevalence was $19 \%(n=504)$.

Table 2. Evaluating nutritional status according to type of institution

\begin{tabular}{|c|c|c|c|c|c|c|c|}
\hline \multirow{3}{*}{ Variables } & \multicolumn{4}{|c|}{ Type of elementary school } & \multirow{2}{*}{\multicolumn{2}{|c|}{ Total group }} & \multirow{3}{*}{ p value ${ }^{(1)}$} \\
\hline & \multicolumn{2}{|c|}{ Private } & \multicolumn{2}{|c|}{ Public } & & & \\
\hline & $\mathrm{N}$ & $\%$ & N & $\%$ & \multicolumn{2}{|c|}{$\mathrm{N} \%$} & \\
\hline \multicolumn{8}{|c|}{ Nutritional status } \\
\hline Obese & 178 & 13,6 & 62 & 4,6 & 240 & 9,0 & $p<0.0001^{*}$ \\
\hline Not obese & 1135 & 86,4 & 1276 & 95.4 & 2411 & 91,0 & \\
\hline Total & 1313 & 100.0 & 1338 & 100,0 & 2,651 & 100,0 & \\
\hline
\end{tabular}

Table 3. Prevalence of dental caries according to type of school

\begin{tabular}{lcccccc}
\hline \multirow{2}{*}{ Wariable } & \multicolumn{3}{c}{ Type of elementary school } & \multicolumn{2}{c}{ Total group } \\
& $\mathrm{N}$ & $\%$ & $\mathrm{~N}$ & $\%$ & $\mathrm{~N}$ & $\%$ \\
\hline Dental caries prevalence & 250 & 11,4 & 354 & 25,4 & 504 & 19,0 \\
Total & 1313 & 100,0 & 1338 & 100,0 & 2651 & 100,0 \\
\hline
\end{tabular}


Table 4 shows a significant association between children who were obese and those who were not in private institutions regarding a single variable (decayed) from the DMFT (decayed, missing and filled teeth) score. Table 5 shows that there was no significant association between DMFT score components and nutritional status in public institutions.

Table 4. Prevalence of DMFT score and components concerning nutritional status-private schools

\begin{tabular}{|c|c|c|c|c|}
\hline \multirow{2}{*}{ Variables } & \multirow{2}{*}{ Statistics } & \multicolumn{2}{|c|}{ Nutritional status } & \multirow{2}{*}{$p$ values ${ }^{[t]}$} \\
\hline & & Obese & Not obese & \\
\hline \multirow[t]{2}{*}{ - Decayed } & Mean & 0,174 & 0,373 & \multirow[t]{2}{*}{$p=0.007^{\circ}$} \\
\hline & SD & 0.727 & 1.253 & \\
\hline \multirow[t]{2}{*}{ - Missing } & Mean & 0,006 & 0,011 & \multirow[t]{2}{*}{$p=0.743$} \\
\hline & SD & 0.075 & 0,180 & \\
\hline \multirow[t]{2}{*}{ - Filled } & Mean & 0,118 & 0,104 & \multirow[t]{2}{*}{$p=0.721$} \\
\hline & $\mathrm{SO}$ & 0.565 & 0.559 & \\
\hline \multirow[t]{2}{*}{ - DMFT } & Mean & 0,298 & 0,493 & \multirow[t]{2}{*}{$p=0.094$} \\
\hline & SD & 0,978 & 1,509 & \\
\hline
\end{tabular}

Table 5. Prevalence of DMFT score and components concerning nutritional status-public schools

\begin{tabular}{|c|c|c|c|c|}
\hline \multirow[b]{2}{*}{ Variable } & \multirow[b]{2}{*}{ Statistics } & \multicolumn{2}{|c|}{ Nutritional status } & \multirow[b]{2}{*}{$p$ value "1 } \\
\hline & & Obese & Not obese & \\
\hline \multirow{2}{*}{ - Decayed } & Mean & 1.016 & 0,927 & $p=0.868$ \\
\hline & SD & 2.214 & 1.984 & \\
\hline \multirow{2}{*}{ - Missing } & Mean & 0.016 & 0,048 & $p=0.489$ \\
\hline & SD & 0.127 & 0,348 & \\
\hline \multirow[t]{2}{*}{ - Filled } & Mean & 0,065 & 0,089 & $p=0.845$ \\
\hline & SD & 0.248 & 0,432 & \\
\hline \multirow[t]{2}{*}{ - DMFT } & Mean & 1,161 & 1,070 & $p=0.836$ \\
\hline & SD & 2,444 & 2,236 & \\
\hline
\end{tabular}

\section{DISCUSSION}

The general prevalence of child obesity among Brazilian preschooler children was found to be in line with that given in the literature (4-6). A small percentile of infantile obesity was observed amongst low socioeconomic level children when considering the type of school as socioeconomic level parameter (Table 2). This finding was in agreement with a previous study (8). The larger prevalence of obesity in high socioeconomic level children could be explained by them adopting low-intensity physical activities together with consuming high-energy value food $(2,3,24)$. The amount of carbohydrates in children's diets has been increasing over the last 10 years as a consequence of recommendations to decrease dietary fat. Unfortunately, neither the nutritional quality of preschoolers' diets nor their physical activity levels are now adequate. 
Dental caries is a public health problem affecting infants and preschool children around the world, although caries prevalence and severity has substantially declined over the past 40 years. The prevalence of dental caries is influenced by a number of risk factors, such as age, dietary pattern or oral hygiene habits. The overall prevalence of dental caries (Table 3) observed in this study was low (19\%) when compared to other studies $(16,20,21)$; however, it was similar to that in a previous report from Macau (15). No recall was made here concerning children's dietary intake because diet is a common risk factor for obesity and dental caries (9).

This study was aimed at examining a possible association between dental caries and obesity. However, when Tables 4 and 5 were analysed, there was no statistical difference in DMFT score between obese and non-obese children, a similar result to previous reports from China (25) and the USA (26) but different to one from France(9) and the USA (28). A statistical difference was only seen between decay and private institution $(\mathrm{p}<0.05 \%)$, where children who were not obese had a higher number of caries than obese ones.

This data contributes towards the extensive discussion regarding the multifactor aspect of both diseases studied $(1,27,29,30)$. The concept of dental caries which was initially based on a model proposed in 1962 (host, diet and microorganisms) (27) has become changed. The modern concept of dental caries includes social and behavioural factors regarding a particular individual (29). In turn, obesity has been associated with diet, genetic and behavioural and psychological factors $(1,31)$.

Choosing healthy food contributes towards preventing obesity and its associated diseases and maintains paediatric patients' oral health. Health professionals should thus focus on the parents of children at risk of becoming overweight/obese and/or underweight by providing them with strategies concerned with bad eating behaviour, such as fussy eating and overeating $(28,32)$.

Though no relationship between dental caries and obesity was found, the high prevalence between childhood obesity and dental caries suggested the need for health policies aimed at reducing this problem and improving children's oral health* 


\section{REFERENCES}

1. Taubes G. As obesity rates rise, experts struggle to explain why. Science 1998; 29: 289-291.

2. Edwards CA, Parrett AM. Dietary fibre in infancy and childhood. Proc Nutr Soc 2003; 62:17-23.

3. Proctor MH, Moore LL, Gao D, Cupples LA, Bradlee ML, Hood MY, Ellison RC. Television viewing and change in body fat from preschool to early adolescence: The Framingham Children's Study. Int J Obes Relat Metab Disord 2003; 27:827-833.

4. Canning P, Courage ML, Frizzell LM, Seifert T. Obesity in a provincial population of Canadian preschool children: differences between 1984 and 1997 birth cohorts. Int J Pediatr Obes 2007; 2:51-57.

5. Kain BJ, Lera ML, Rojas P J, Uauy DR. Obesity among preschool children of Santiago, Chile. Rev Med Chil 2007; 1:63-70.

6. Pisabarro R. Prevalencia de la obesidad en el Uruguay. Rev Panam Salud Pública 2005; 17:119.

7. Wake M, Hardy P, Canterford L, Sawyer M, Carlin JB. Overweight, obesity and girth of Australian preschoolers: prevalence and socio-economic correlates. Int J Obes 2007; 31:1044-1051.

8. Arteaga H, Dos Santos JE, Dutra de Oliveira JE. Obesity among schoolchildren of different socioeconomic levels in a developing country. Int J Obes 1982;6(3):291-297.

9. Bailleul-Forestier I, Lopes K, Souames M, Azoguy-Levy S, Frelut M, Boy-Lefevre M. Caries experience in a severely obese adolescent population. Int J Paediatr Dent 2007; 17:358-363.

10. Fejerskov $\mathrm{O}$. Changing paradigms in concepts on dental caries: consequences for oral health care. Caries Res 2004; 8:182-191.

11. Frencken JE, Kalsbeek $\mathrm{H}$, Verrips $\mathrm{GH}$. Has the decline in dental caries been halted? Changes in caries prevalence among 6- and 12 -year-old children in Friesland, 1973-1988. Int Dent J 1990; 40:225-230.

12. Carvalho JC, Van Nieuwenhuysen JP, D'Hoore W. The decline in dental caries among Belgian children between 1983 and 1998. Community Dent Oral Epidemiol 2001;29:55-61.

13. Bönecker M, Marcenes W, Sheiham A. Caries reductions between 1995, 1997 and 1999 in preschool children in Diadema, Brazil. Int J Paediatr Dent 2002; 12: 183-188.

14. Narvai PC, Frazão P, Roncalli AG, Antunes JLF. Dental caries in Brazil: decline, polarization, inequality and social exclusion. Rev Pan Am Salud Publica 2006; 19:385-393.

15. King NM, Wu II, Tsai JS. Caries prevalence and distribution, and oral health habits of zero- to four-year-old children in Macau, China. J Dent Child 2003; 70: 243-249.

16. Rosenblatt A, Zarzar P. The prevalence of early childhood caries in 12- to 36-month-old children in Recife, Brazil. J Dent Child 2002: 69:1-6.

17. Ramos-Gomez FJ, Tomar SL, Ellison J, Artiga N, Sintes J, Vicuna G. Assessment of early childhood caries and dietary habits in a population of migrant Hispanic children in Stockton, California. J Dent Child 2003; 66: 395-403.

18. Hashim R, Thomson W M. . Ayers K M S, Lewsey J D, Awad M. Dental caries experience and use of dental services among preschool children in Ajman, UAE. Int J Paediatr Dent 2006; 16: 257-262.

19. Sowole A, Sote E, Folayan M. Dental caries pattern and predisposing oral hygiene related factors in Nigerian preschool children. Eur Archs Paediatr Dent 2007; 8:206-210.

20. Campus G, Lumbau A, Sanna AM, Solinas G, Lugliè P, Castiglia P. Oral health condition in an Italian preschool population. Eur J Paediatr Dent 2004; 5:86-91.

21. Peressin S, Leake JL, Mayhall JT, Maar M, Trudeau R. Prevalence of early childhood caries among First Nations children, District of Manitoulin, Ontario. Int J Paediatr Dent 2004; 14: $101-110$.

22. OMS. Encuestas de la salud buçodental: métodos básicos. Ginebra: Organización Mundial de la salud; 1997. 
23. WHO. Use and interpretation of anthropometrics indicators of nutricional status. Bull. World Health Organization. 1989;64:929-941.

24. Feesen M. Prevalence of obesity in children in Alabama and Texas participating in social programs. J Amer Med Assoc 2003; 289:1780-1781.

25. Chen W, Chen P, Chen SC, Shih WT, Hu HC. Lack of association between obesity and dental caries in three-year-old children. Zhonghua Min Guo Xiao Er Ke Yi Xue Hui Za Zhi 1998; 39:109-111.

26. Kopycka-Kedzierawski DT, Auinger P, Billings RJ, Weitzman M. Caries status and overweight in 2-to 18-year-old US children: findings for national surveys. Community Dent Oral Epidemiol 2008; 36(2): 157-167.

27. Kantovitz KR, Pascon FM, Rontani RM, Gaviao MB. Obesity and dental caries. A systematic review. Oral Health Prev Dent 2006; 4: 137-144.

28. Marshall TA, Eichenberger-Gilmore JM, Broffitt BA, Warren JJ, Levy SM. Dental caries and childhood obesity: roles of diet and socioeconomic status. Community Dent Oral Epidemiol 2007; 35:449-458.

29. Keyes, P.H. Recent advances in dental research. Bacteriology. Int Dent J 1962; 12:443-464.

30. Fejerskov O. Changing paradigms in concepts on dental caries: consequences for oral health care. Caries Res 2004; 8:182-191.

31. Dubois L, Farmer A, Girard M, Peterson K, Tatone-Tokuda F. Problem eating behaviors related to social factors and body weight in preschool children: A longitudinal study. Int J Behav Nutr Phys Act 2007; 4:1-10.

32. Bellows L, Anderson J, Gould SM, Auld G. Formative Research and Strategic Development of a Physical Activity Component to a Social Marketing Campaign for Obesity Prevention in Preschoolers. J Community Health 2008. [Internet]. On line http:// www.springerlink.com/content/0437804m68537202/ Accessed: January 21, 2008. 